\title{
Zalety symultanicznych badań ultradźwiękowych techniką Phased Array i TOFD złączy spawanych
}

\author{
Advantages of simultaneous Phased Array \\ and TOFD ultrasonic testing of welded joints
}

\section{Streszczenie}

W pracy opisano możliwości badawcze symultanicznych badań Phased Array i TOFD stosowanych do kontroli jakości doczołowych złączy spawanych. Przeanalizowano zalety łączenia omawianych technik badań ultradźwiękowych. Zilustrowano je wieloma przykładami wyników badań, zawierających wskazania od różnych rodzajów niezgodności spawalniczych, obrazujących komplementarność technik Phased Array i TOFD. Artykuł kierowany jest do personelu badań nieniszczących oraz personelu nadzoru spawalniczego, chcącego poznać zalety stosowania nowoczesnych technik ultradźwiękowych.

Słowa kluczowe: badania ultradźwiękowe spoin; Phased Array; TOFD

\begin{abstract}
The paper describes capabilities of simultaneous Phased Array and TOFD testing used for quality control of butt welded joints. The advantages of combining these techniques to ultrasonic testing have been analyzed. They have been illustrated by many examples of research results, contain indications of different types of imperfections, showing the complementarity of Phased Array and TOFD ultrasonic techniques. Article is addressed to NDT personnel and welding supervision personnel interested in advantages of advanced ultrasonic techniques.
\end{abstract}

Keywords: ultrasonic testing of welds; Phased Array; TOFD

\begin{abstract}
Wstęp
Badania złączy spawanych ultradźwiękową techniką czasu przejścia wiązki dyfrakcyjnej TOFD są stosowane w warunkach przemysłowych już od lat siedemdziesiątych XX w. [1]. Jednakże dopiero pod koniec lat dziewięćdziesiątych można było zaobserwować znaczący wzrost zastosowania tej metody badań, tak za granicą, jak i w Polsce [2]. W tym czasie powstały także pierwsze dokumenty normatywne znacznie ułatwiające opracowanie procedur badawczych. Od 2011 r. metoda TOFD jest całkowicie znormalizowana, zarówno w aspekcie wykonawstwa badań (PN-EN ISO 10863) jak i kryteriów akceptacji (PN-EN ISO 15626) skorelowanych z odpowiednimi poziomami jakości złączy spawanych [3,4]. Fakt ten uporządkował i znacząco ułatwił stosowanie badań złączy spawanych tą techniką. Ponieważ obszarem zastosowania badań TOFD są przede wszystkim złącza o bardzo dużej odpowiedzialności (rurociągi, zbiorniki ciśnieniowe, itd.) wymagają one pokrycia dodatkowym badaniem stref martwych TOFD. Są to obszary przy powierzchni skanowania oraz przy powierzchni przeciwległej o braku lub zaniżonej wykrywalności. Wykrywalność nieciągłości
\end{abstract}

w tych strefach zależy od wielkości nieciągłości oraz jej odległości od powierzchni.

Dotychczas do pokrycia stref martwych stosowano przeważnie połączenie TOFD z metodą puls - echo (PE). Wymagała ona stosowania wielogłowicowych skanerów wyposażonych dodatkowo w dwie głowice skośne fal poprzecznych skierowane na wykrywanie nieciągłości w grani spoiny oraz dwie głowice fal podpowierzchniowych odpowiedzialne za wykrywanie nieciągłości znajdujących się tuż pod powierzchnią skanowania [5]. Rozwiązanie to wymagało niestety bardzo precyzyjnego prowadzenia skanera w stosunku do osi spoiny. W przeciwnym przypadku wskazania od geometrii grani mogłyby zostać zinterpretowane jako wskazania od niezgodności w przetopie spoiny.

Obecnie optymalnym uzupełnieniem badań TOFD jest technika Phased Array (PA), znacznie wygodniejsza i wiarygodniejsza od zmechanizowanych, wielogłowicowych badań PE. Możliwość jej szerszego, przemysłowego zastosowania wiąże się ze zwiększeniem dostępności sprzętu i znacznym spadkiem jego cen. Kompletne wyposażenie

Mgr inż. Rafał Kaczmarek - Politechnika Częstochowska; dr inż. Karol Kaczmarek, dr hab. inż. Jacek Słania prof. IS - Instytut Spawalnictwa.

Autor korespondencyjny/Corresponding author. rafal.kaczmarek133@gmail.com 
do badań PA+TOFD wciąż jest drogie, jednakże jego ceny nie są aż tak wysokie jak przed kilkoma laty. Dlatego też na ich zakup może pozwolić sobie coraz to więcej polskich firm wykonujących badania NDT. Ponadto wdrażanie badań PA+TOFD ze względu na swoją innowacyjność może być dofinansowane $z$ odpowiednich programów rozwojowych realizowanych przez Narodowe Centrum Badań i Rozwoju [6]. Nie bez znaczenia jest również fakt, że kończy się etap normowania badań złączy spawanych techniką Phased Array, co znacznie ułatwi wdrażanie ich w przemyśle. W 2012 r. wprowadzono normę EN ISO 13588 regulującą kwestie wykonywania badań złączy spawanych techniką PA. Z kolei w ubiegłym roku opublikowano projekt normy ISO/DIS 19285 dotyczącej kryteriów akceptacji wskazań skorelowanych z odpowiednimi poziomami jakości złączy spawanych. Można więc przypuszczać, że wprowadzenie tejże normy powinno nastąpić w niedługim czasie. Ponieważ podejście przytoczonych powyżej norm do wykonawstwa badań oraz oceny wskazań w technikach TOFD i PA jest zbieżne, daje to formalne podstawy do wprowadzenia badań PA+TOFD na polskim rynku badań nieniszczących.

$Z$ tego względu istnieje realna potrzeba omawiania zagadnień związanych z badaniami PA+TOFD, prezentowania ich możliwości badawczych oraz systemowe poszerzanie wiedzy personelu kontroli jakości oraz nadzoru spawalniczego. Umożliwi to lepsze zrozumienie potrzeby stosowania tej metody badań, co finalnie przyczyni się do zwiększenia niezawodności wykonywanych konstrukcji spawanych.

\section{Zalety łączenia badań Phased Array oraz TOFD}

Techniki Phased Array oraz TOFD oparte są na odmiennych sposobach detekcji wskazań od nieciągłości. Dlatego też wzajemnie się uzupełniają i stosowane symultanicznie są obecnie najskuteczniejszą metodą badania złączy spawanych [7].

Technika PA jest oparta na zasadach analogicznych do konwencjonalnych badań ultradźwiękowych metodą echa. Różnica polega jedynie na zastosowaniu głowic wieloprzetwornikowych, umożliwiających elektroniczne zmiany kąta wiązki ultradźwiękowej (skan sektorowy) lub zmiany położenia osi wiązki (elektroniczny skan liniowy). Dlatego też badania PA wykazują podobne ograniczenia co konwencjonalne badania UT:

- ograniczona wykrywalność nieciągłości płaskich niekorzystnie zorientowanych w stosunku do wiązki ultradźwiękowej (np. przyklejenia międzywarstwowe),

- ograniczona wykrywalność nieciągłości przestrzennych powodujących rozproszenie wiązki ultradźwiękowej i w jego efekcie bardzo słabe echo (pęcherze, gniazda pęcherzy),

- niewielka dokładność wymiarowania wskazań, szczególnie w kierunku głębokości,

- duża ilość wskazań od geometrii (echa kształtu grani i lica) czasem błędnie interpretowanych jako wskazania od nieciągłości. Jednocześnie badania PA wykazują szereg korzyści:

- możliwość określenia rodzaju niezgodności na zobrazowaniu typu S (przyklejenie brzegowe, pęknięcie, brak przetopu, gniazdo pęcherzy, itd.),

- duża wykrywalność nieciągłości płaskich zorientowanych korzystnie w stosunku do wiązki ultradźwiękowej (przyklejenia brzegowe, pęknięcia w SWC),

- duża wykrywalność niezgodności tworzących naroże prostokątne z powierzchnią elementu (braki przetopu oraz przyklejenia w grani spoin jednostronnych, pęknięcia wychodzące na powierzchnię),

- łatwość interpretacji wskazań od geometrii dzięki dostępowi do zobrazowania typu B i S oraz wyników badań z głowicy usytuowanej po przeciwległej stronie spoiny (dotyczy badań symultanicznych prowadzonych dwoma głowicami PA).

Technika TOFD oparta jest nie na odbiciu wiązki ultradźwiękowej od nieciągłości, lecz na zjawisku dyfrakcji (ugięcia) na jej krawędziach [3]. Z tego względu wykazuje następujące cechy:

- bardzo dobra wykrywalność nieciągłości płaskich, w niewielkim stopniu uzależniona od ich orientacji,

- możliwość precyzyjnej oceny głębokości zalegania oraz wysokości wskazań, znacznie dokładniejszej niż w badaniu metodą echa (o ile pozwala na to rozdzielczość przestrzenna w miejscu zalegania nieciągłości),

- wysoka czułość badania, pozwalająca na uzyskiwanie wskazań od bardzo małych nieciągłości, o wysokości nawet rzędu 0,1 mm [8],

- duża wiarygodność badania, niewielka ilość fałszywych wskazań [1].

Jak wspomniano wcześniej, mankamentem badań techniką TOFD są strefy martwe. Są to obszary przy powierzchniach elementu zakryte na zobrazowaniu TOFD impulsem fali podpowierzchniowej LW oraz fali odbitej BW. W przypadku istnienia niewielkich nieciągłości w tych obszarach, ich słabe sygnały mogą być niezauważalne ze względu na obecność znacznie silniejszych impulsów LW i BW.

Problemem występującym przy ocenie obrazów TOFD może być także duża ilość wskazań punktowych, pochodzących od drobnych nieciągłości. Dotyczy to zwłaszcza złączy o większych grubościach, gdzie przy dużej ilości ściegów istnieje większe prawdopodobieństwo powstania wielu nieciągłości. Zmniejszają one czytelność obrazu TOFD i mogą skutkować przeoczeniem słabych wskazań od krawędzi nieciągłości, np. pęknięć. Wówczas jedynym rozwiązaniem jest brak akceptacji tegoż odcinka złącza lub weryfikacja inną metodą badań.

Jak widzimy, z analizy zalet i ograniczeń obydwu technik wynika, że optymalnym rozwiązaniem jest stosowanie badań TOFD w połączeniu z PA. Rozwiązanie to nie zwiększa znacząco czasu badania, rozumianego jako czas skanowania złącza, a w efekcie daje pełny obraz istniejących nieciągłości w spoinie (czas przygotowania do badań jest zazwyczaj znacznie dłuższy ze względu na duży stopień skomplikowania systemu badawczego PA+TOFD). Aby zilustrować korzyści płynące z zastosowania symultanicznych badań PA+TOFD w dalszej części artykułu zamieszczono wyniki badań, zawierające wskazania różnych niezgodności spawalniczych. Dobrano je w taki sposób, by obrazowały wzajemną komplementarność technik PA i TOFD, a także przedstawiały czytelnikom możliwości badawcze tego rozwiązania.

\section{Wyniki badań PA+TOFD}

Badania wykonano przy użyciu wielokanałowego defektoskopu ultradźwiękowego Omniscan MX2 wyposażonego w spliter oraz adapter umożliwiający jednoczesne podłączenie dwóch głowic PA oraz pary głowic TOFD (rys. 1). Zastosowano dwie 32-elementowe głowice wieloprzetwornikowe 5L32-19.2x10-A31 o częstotliwości 5 MHz i aktywnej aperturze 19,2 mm oraz kliny SA31-N55S-IHC. Prawa opóźnień opracowano w taki sposób, aby każda z zastosowanych wiązek była zogniskowana w pobliżu linii wtopienia spoiny. Zastosowano skan sektorowy ze sterowaniem wiązki 
w zakresie kątowym $40 \div 70^{\circ}$. Wykonano kalibrację kątową ACG oraz w drodze wiązki TCG, po czym ustawiono poziom odniesienia na otworze cylindrycznym o średnicy $3 \mathrm{~mm}$. Ponadto zastosowano dwie szerokopasmowe głowice do badań TOFD C563-SL o częstotliwości $10 \mathrm{MHz}$ i średnicy przetworników $3 \mathrm{~mm}$ wraz z klinami ST1-70L-IHS o kącie wprowadzenia fali podłużnej równym $70^{\circ}$. Kalibrację TOFD wykonano na próbkach odniesienia o grubości znanej z dokładnością do $0,05 \mathrm{~mm}$. Głowice do badań zamontowano w skanerze HSMT-Flex wyposażonym w enkoder. Wykorzystany do badań zestaw badawczy wraz z próbką odniesienia pokazano na rysunku 1 .

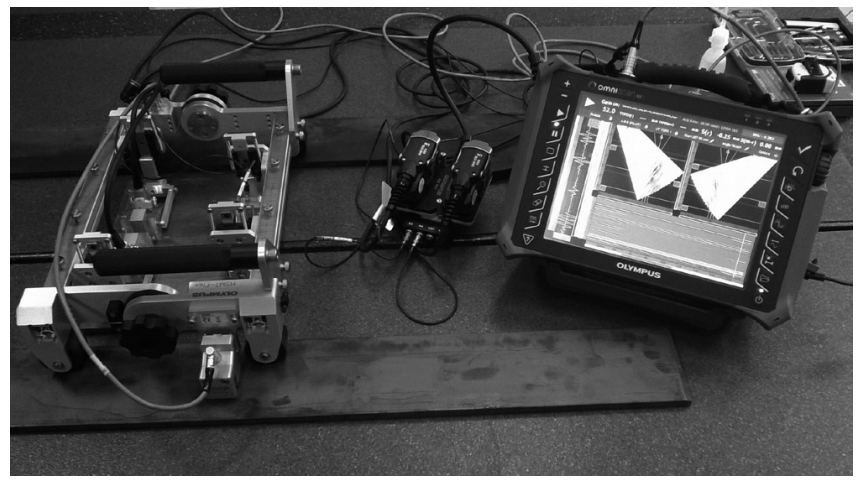

Rys. 1. Zestaw do badań PA+TOFD zawierający defektoskop wielokanałowy Omniscan MX2, skaner z głowicami PA oraz TOFD a także próbkę odniesienia do sprawdzenia ustawień i wykrywalności Fig. 1. Ultrasonic system for PA + TOFD testing, containing Omniscan MX2 flaw detector, scanner with PA and TOFD probes as well as a reference sample for settings and detectability verification

Do sprawdzenia ustawień i wykrywalności wykorzystano próbki odniesienia o grubościach 10, 12 i 16 mm z trzema reflektorami referencyjnymi:

- otworem cylindrycznym o średnicy 2,5 mm umiejscowionym w połowie grubości próbki,

- otworem cylindrycznym o średnicy $2 \mathrm{~mm}$ umiejscowionym $4 \mathrm{~mm}$ pod powierzchnią skanowania,

- szczeliną o szerokości 0,2 mm i wysokości $1 \mathrm{~mm}$ wykonaną od powierzchni przeciwległej.

Na rysunku 2 przedstawiono wyniki badań złącza spawanego o grubości $10 \mathrm{~mm}$ ze spoiną czołową ukosowaną na V. W dolnej części rysunku przedstawiono zobrazowanie typu B z badań TOFD w układzie długość złącza (poziomo) - czas przelotu wiązki (pionowo), zawierające obszar między falą podpowierzchniową LW i odbitą BW. Zobrazowanie to jest dużą zaletą badań TOFD, gdyż na jednym obrazie widzimy wszystkie istotne zarejestrowane wskazania (podobnie jak na radiogramie spoiny, z tym wyjątkiem, że obserwujemy rzut z boku, a nie z góry spoiny). Widzimy na nim dwa wyraźne wskazania. Duże wskazanie między 90 a $120 \mathrm{~mm}$ złącza jest łatwe do klasyfikacji jako wskazanie wychodzące na powierzchnię przeciwległą. Jednakże klasyfikacja zaznaczonego wskazania umiejscowionego na $35 \div 45 \mathrm{~mm}$ złącza jest trudna, gdyż nie widzimy dwóch oddzielnych sygnałów dyfrakcyjnych czy też towarzyszącego przerwania fali BW lub LW. Z tego względu przy ocenie wskazania na podstawie badań TOFD musielibyśmy zakładać najbardziej niekorzystny wariant lub weryfikować akceptowalność wskazania inną techniką. Wynika to z faktu, iż nie jesteśmy w stanie ocenić rodzaju wskazania (wewnętrzne, wychodzące na powierzchnię) oraz wyznaczyć jego wysokości, która jest podstawą do akceptacji. Wykonując symultaniczne badania PA+TOFD opisywany dylemat może być łatwo zweryfikowany. Jak widzimy na zobrazowaniu $S$ z drugiej grupy PA (rys. 2, prawa strona) mamy do czynienia z nieciągłością wewnętrzną nie wychodzącą na powierzchnię $\mathrm{w}$ postaci przyklejenia brzegowego. Świadczy o tym charakterystyczna, kierunkowa zdolność odbicia a także lokalizacja wskazania na ściance rowka spawalniczego. Ponadto obserwujemy również typowe dla badań techniką echa wskazania od grani, tzw. echa kształtu, pojawiające się każdorazowo po przeciwległej stronie osi spoiny [9].

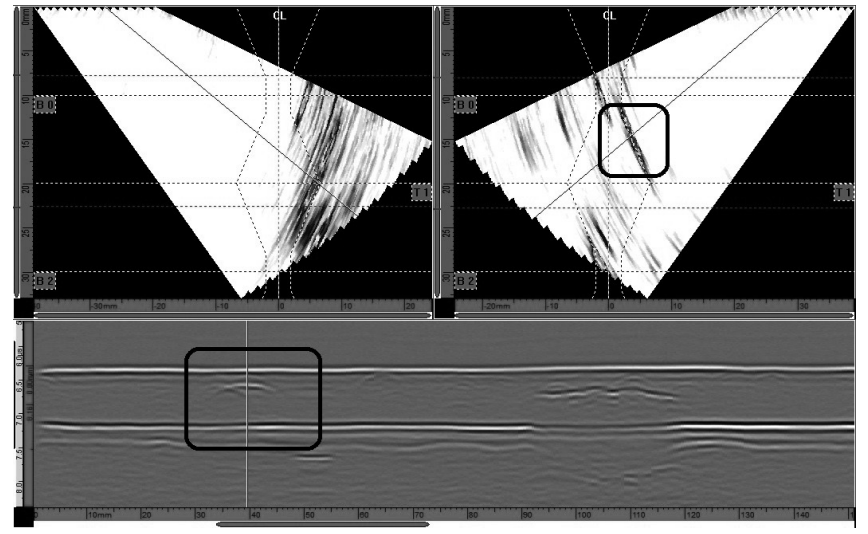

Rys. 2. Wyniki badań PA+TOFD złącza spawanego o grubości $10 \mathrm{~mm}$ w miejscu występowania przyklejenia brzegowego. Badania PA umożliwiają określenie rodzaju wskazania

Fig. 2. The ultrasonic PA + TOFD examination results of welded joint, thickness of $10 \mathrm{~mm}$, at the location of sidewalls lack of fusion. PA testing allows to specify the type of indication

Na rysunku 3 przedstawiono wyniki badań złącza o grubości $12 \mathrm{~mm}$. W tym przykładzie obraz TOFD umożliwia jednoznaczne określenie rodzaju zaznaczonego wskazania jako wychodzącego na powierzchnię skanowania. Dodatkowo na podstawie TOFD możemy precyzyjnie wyznaczyć wysokość nieciągłości. Niestety ta technika badań nie pozwoli na wyznaczenie pozycji nieciągłości w kierunku osi y (lokalizacja na szerokości spoiny) jak również nie możemy na jej podstawie określić rodzaju niezgodności. Takie informacje uzyskamy poprzez analizę zobrazowania typu S z lewej głowicy PA. Widzimy na nim charakterystyczne wskazanie typowe dla pęknięcia wychodzącego od powierzchni skanowania. Składa się ono z odbicia od prostokątnego naroża tworzonego przez pęknięcie z kilkoma mniejszymi echami powstałymi od załamań pęknięcia, które wykazują korzystną orientację w stosunku do wiązki ultradźwiękowej. W trakcie przesuwania kursora danych echa od załamań, na przemian powstają i znikają wzdłuż linii pęknięcia. Dzięki temu

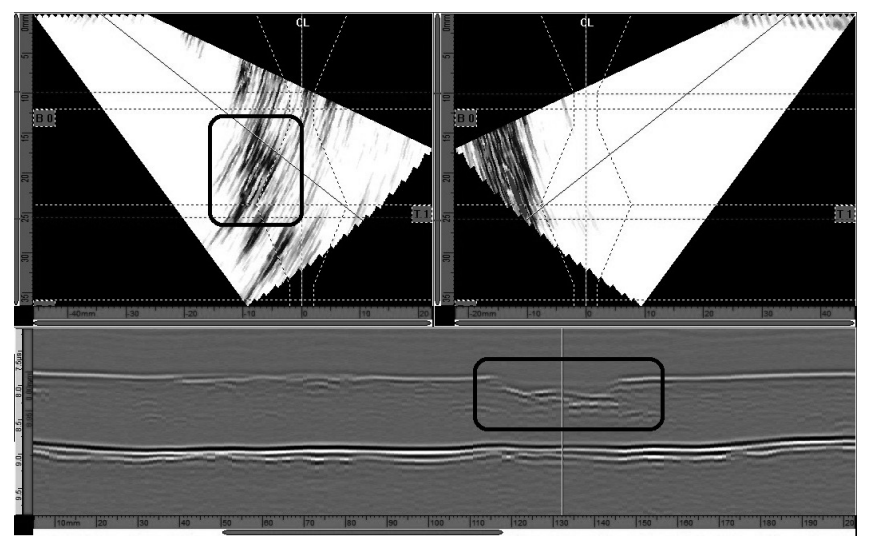

Rys. 3. Wyniki badań PA+TOFD złącza spawanego o grubości $12 \mathrm{~mm}$ w miejscu występowania pęknięcia wychodzącego na powierzchnię skanowania

Fig. 3. The PA + TOFD test results of welded joint, thickness of $12 \mathrm{~mm}$ at the location of scanning surface breaking crack in the welded joint 
możemy nie tylko precyzyjnie zlokalizować nieciągłość po osi y jako znajdującą się w strefie wpływu ciepła, ale ponadto $z$ dużym prawdopodobieństwem jesteśmy $w$ stanie określić rodzaj powstałej niezgodności. Ma to duże znaczenie praktyczne ze względu na możliwość wprowadzenia do procesu spawania zabiegów technologicznych zapobiegających powstawaniu pęknięć.

$\mathrm{Na}$ rysunku 4 pokazano kolejny przykład wykorzystania badań PA+TOFD do określenia rodzaju niezgodności. $\mathrm{Na}$ zobrazowaniu typu S z głowic PA widać bardzo słabe wskazania o niskiej amplitudzie wynoszącej ok. 30\% pełnej wysokości ekranu (kolor niebieski). Tak niska wysokość echa przy amplitudowych kryteriach akceptacji nie daje podstaw do przyjęcia wskazania za nieakceptowalne. Jest to typowa sytuacja w przypadku wykrywania gniazda pęcherzy w metodzie echa. Nieciągłość tego rodzaju powoduje niemal całkowite rozproszenie wiązki, skutkujące powstaniem echa o bardzo niskiej amplitudzie, często poniżej poziomu oceny. Jednakże w przypadku jednoczesnego dostępu do wyników TOFD wykrycie i ocena wskazań od gniazda pęcherzy jest znacznie łatwiejsza. Wynika to $z$ faktu, że rozproszone na dużej liczbie pęcherzy sygnały ultradźwiękowe dochodząc do głowicy TOFD posiadają amplitudę zbliżoną do amplitudy sygnałów dyfrakcyjnych ugiętych na wierzchołkach nieciągłości. Stąd ich wykrycie w badaniach TOFD będzie znacznie łatwiejsze niż w badaniach metodą echa (rys. 4).

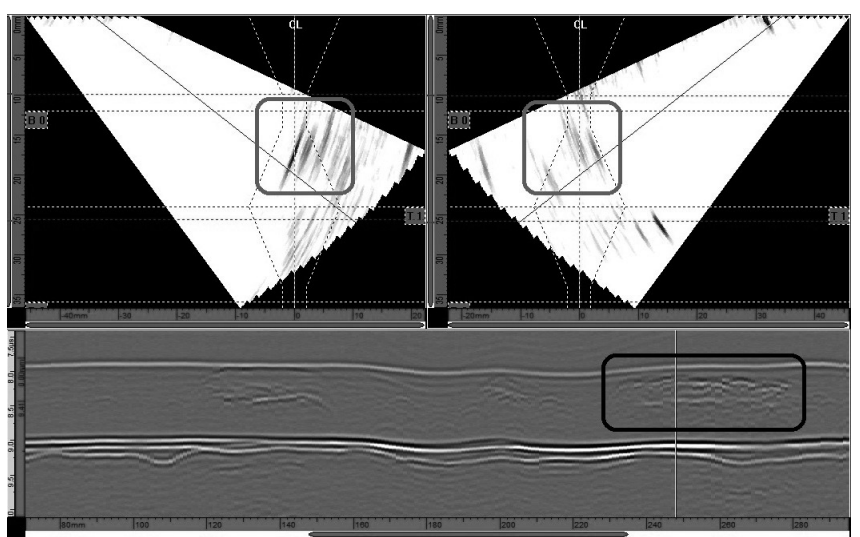

Rys. 4. Wyniki badania PA+TOFD złącza spawanego o grubości $12 \mathrm{~mm}$ w miejscu występowania gniazda pęcherzy

Fig. 4. The results of ultrasonic PA + TOFD examination of weld joint, thickness of $12 \mathrm{~mm}$, at the location where localized porosity occurred

W przypadku wyznaczania głębokości czy wysokości wskazań znacznie precyzyjniejsze wyniki uzyskuje się wykorzystując sygnały dyfrakcyjne od wierzchołków nieciągłości uzyskane w technice TOFD niż bazując na sygnałach odbitych w metodzie echa. W drugim przypadku uzyskany wynik może być znacznie przeszacowany, gdyż w dużym stopniu zależy on od szerokości wiązki ultradźwiękowej w miejscu występowania nieciągłości. Z tego względu najkorzystniejszym rozwiązaniem w prezentowanym na rysunku 5 przykładzie byłoby wymiarowanie wysokości wskazania na podstawie obrazu TOFD. Możemy uzyskać wówczas wyniki z dokładnością rzędu dziesiątych części milimetra [1]. Oczywiście zależy ona od kilku czynników, takich jak zastosowana częstotliwość głowic, rozstaw głowic PCS czy pozycja wskazania w osi y. Mimo to uzyskany wynik będzie znacznie bardziej wiarygodny niż w przypadku pomiaru metodą echa. Z kolei badania Phased Array mogą posłużyć do określenia rodzaju wskazania. Na rysunku 4 (zobrazowanie typu S) widzimy silne wskazania na głębokości równej grubości materiału badanego, umiejscowione w grani po prawej stronie osi spoiny. Są one charakterystyczne dla naroża prostokątnego, skutecznie odbijającego wiązkę ultradźwiękową (z wyjątkiem kąta $60^{\circ}$ ). Stąd, z dużym prawdopodobieństwem możemy określić rodzaj wykrytej nieciągłości jako przyklejenie w grani.

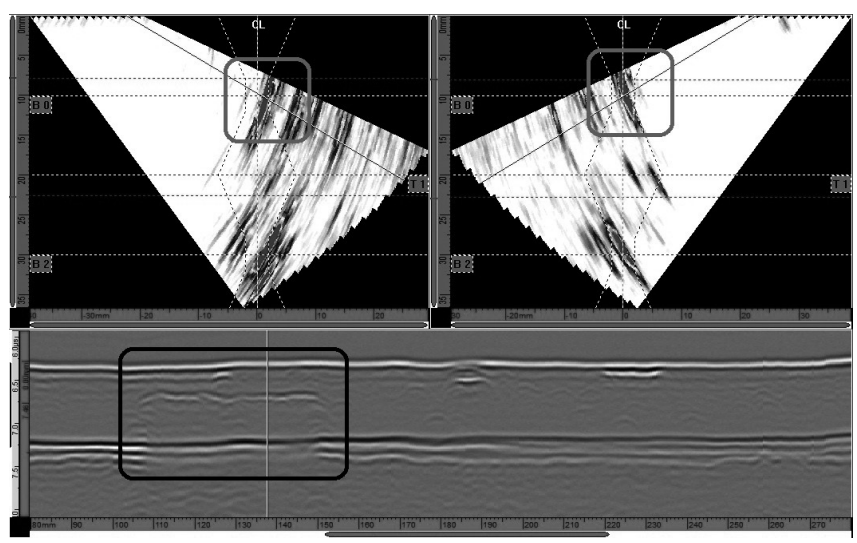

Rys. 5. Wyniki badania PA+TOFD złącza spawanego o grubości $10 \mathrm{~mm}$ ze wskazaniem od przyklejenia w grani

Fig. 5. The results of ultrasonic PA + TOFD examination of welded joint, thickness of $10 \mathrm{~mm}$, at the location of root lack of fusion

W badaniach TOFD mamy do czynienia $z$ istnieniem stref martwych przy powierzchni skanowania oraz przy powierzchni przeciwległej. Ich wielkość zależy od parametrów badania, takich jak częstotliwość, odległość między środkami głowic PCS oraz stopień wytłumienia głowic [8]. Mimo, że obszar zajmowany przez strefę martwą przy powierzchni przeciwległej jest niewielki, to jednak w nim mogą występować bardzo niebezpieczne niezgodności zlokalizowane w grani spoiny, takie jak braki przetopu, przyklejenia w grani czy pęknięcia. W przypadku, gdy nieciągłości te są niewielkie, istnieje duże ryzyko, że mogą być one niezauważone na obrazie TOFD. Stąd częsta potrzeba dodatkowego pokrycia tego obszaru inną techniką badań. Najlepiej do tego celu wykorzystać technikę PA, która umożliwia skuteczne wykrycie nawet niewielkich nieciągłości w obszarze grani spoiny. Na rysunku 6 przedstawiono wynik badania złącza zawierającego niezgodność w grani spoiny o niewielkiej wysokości. Jak widzimy, na obrazie TOFD w obszarze między falą podpowierzchniową LW a odbitą BW jest ona praktycznie niezauważalna. Tylko $\mathrm{w}$ zakresie fali transformowanej możemy doszukać się niewielkiego wskazania. Wskazania w tej strefie nie dają jednak możliwości wymiarowania. Ta sama nieciągłość jest dobrze widoczna na wynikach

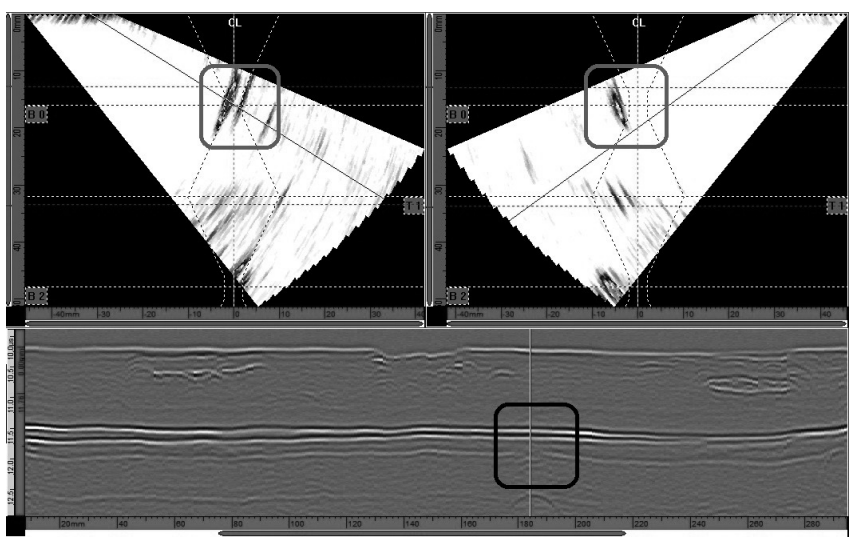

Rys. 6. Wyniki badań PA+TOFD złącza spawanego o grubości $16 \mathrm{~mm}$ z wskazaniem od niezgodności w grani spoiny. Wyniki PA umożliwiają ocenę nieciągłości trudnej do wykrycia na obrazie TOFD ze względu na obecność strefy martwej

Fig. 6. The results of ultrasonic PA + TOFD examination of welded joint, thickness of $16 \mathrm{~mm}$, at the location of root flow. PA technology makes possible detection of discontinuity, that is difficult to detect in TOFD examination, because of dead zone 
badań PA, zarówno na S-skanie, jak i na pozostałych zobrazowaniach (rys. 6 i 7). Najbardziej przydatnym do oceny i wymiarowania tego rodzaju wskazań jest zobrazowanie typu B [9]. Umożliwia ono łatwe i skuteczne odróżnienie wskazań rzeczywistych nieciągłości usytuowanych w grani spoiny od dużej ilości silnych wskazań od geometrii grani, tzw. ech kształtu (rys. 7).

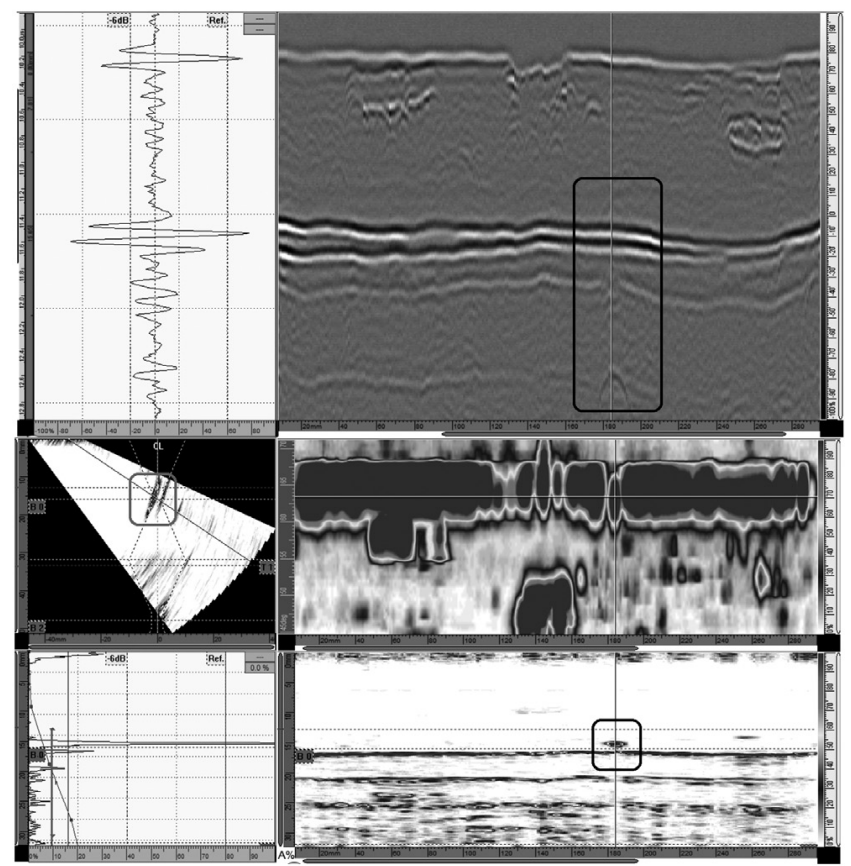

Rys. 7. Pozostałe rodzaje zobrazowań (A, B, C, S) z lewej głowicy PA z badania złącza przedstawionego na rysunku 6 . Na zobrazowaniu typu $B$ łatwo zauważalne wskazanie usytuowane $w$ grani spoiny na tle wskazań od geometrii grani

Fig. 7. Other types of display (A, B, C, S-scan) of results from the left ultrasonic probe (results previously shown in Figure 6). On B-scan representation the indication can be seen against strong indication originating from root geometry

Podobnie sytuacja przedstawia się w przypadku strefy martwej przy powierzchni skanowania. Ponieważ jest ona większa od strefy martwej przy powierzchni przeciwległej, to $w$ konsekwencji może utrudnić wykrycie i ocenę większych niezgodności. Na rysunku 8 przedstawiono obraz TOFD złącza o grubości $10 \mathrm{~mm}$. W zaznaczonym fragmencie wskazaniem nieciągłości umiejscowionej w strefie martwej jest ledwo zauważalne przesunięcie fali podpowierzchniowej ku dołowi (do dłuższych czasów). W praktyce badań przemysłowych przy ocenie złącza na podstawie samej techniki TOFD wskazanie to mogłoby zostać pominięte. W przypadku zapewnienia dodatkowego pokrycia obszaru strefy martwej badaniem PA możemy bez trudu wykryć niewielkie przyklejenie brzegowe usytuowane tuż pod powierzchnią skanowania (rys. 8).

$\mathrm{Na}$ rysunku 9 przedstawiono obraz TOFD zawierający dużą ilość różnorodnych wskazań. Są one trudne do sklasyfikowania wg wytycznych podanych w normie PN-EN ISO
10863. Dodatkowo, występowanie dużej ilości mniejszych nieciągłości niesie ryzyko, że ich sygnały mogą utrudnić wykrycie i ocenę wskazań od krawędzi bardziej niebezpiecznych, dużych nieciągłości płaskich. Następuje wówczas interferencja sygnałów od wszystkich nieciągłości znajdujących się na drodze wiązki ultradźwiękowej w kierunku szerokości badanego złącza. Nieoceniona jest wówczas możliwość weryfikacji takowego fragmentu spoiny przy pomocy badań PA, dających znacznie większe możliwości interpretacji wskazań. Analizując zaznaczony fragment obrazu TOFD trudno jest jednoznacznie sklasyfikować znajdujące się tam wskazanie (rys. 9). Dzięki możliwości weryfikacji przy pomocy PA możemy stwierdzić obecność kilku przyklejeń brzegowych usytuowanych na obydwu ściankach rowka.

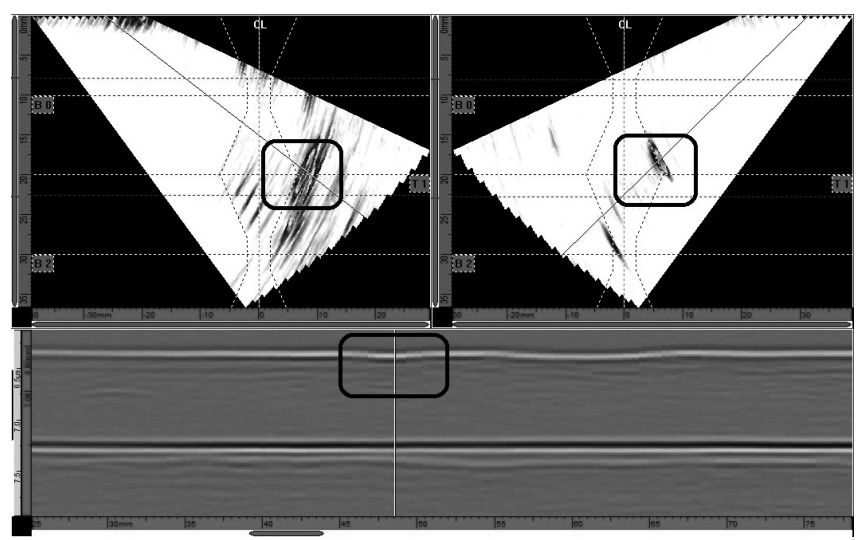

Rys. 8. Wyniki badania PA+TOFD złącza spawanego o grubości $10 \mathrm{~mm}$ ze wskazaniem od przyklejenia brzegowego usytuowanego przy powierzchni lica. W badaniu TOFD wykrycie niezgodności jest znacznie utrudnione

Fig. 8. The results of ultrasonic PA + TOFD examination of welded joint, thickness of $10 \mathrm{~mm}$, at the location of side wall lack of fusion, located from the face side of the joint. The discontinuity is very difficult to detect by TOFD inspection

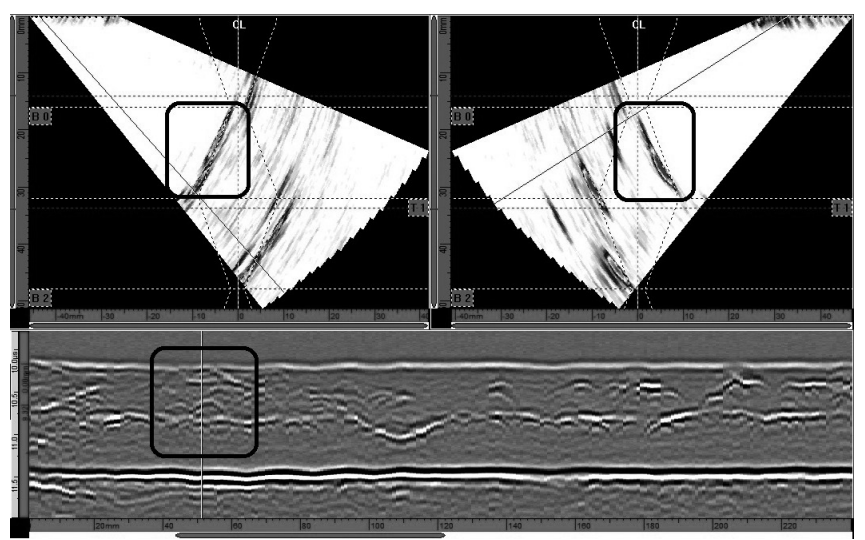

Rys. 9. Wyniki badań PA+TOFD złącza spawanego o grubości $16 \mathrm{~mm}$ ze wskazaniem od przyklejeń brzegowych, trudnych do interpretacji na podstawie samego obrazu TOFD

Fig. 9. The results of ultrasonic PA + TOFD inspection of welded joint, thickness of $16 \mathrm{~mm}$, with indications that are difficult to be interpreted by TOFD alone

\section{Podsumowanie i wnioski}

Zaprezentowane wyniki badań obrazują, jak skuteczną metodą wykrywania niezgodności spawalniczych są symultaniczne badania PA+TOFD. Obie zastosowane techniki ultradźwiękowe są wzajemnie komplementarne, co powoduje znaczące zwiększenie wiarygodności badania. W obszarach, w których badania TOFD posiadają pewne ograniczenia, technika PA jest skutecznym narzędziem uzupełniającym. Obszary te to przede wszystkim pokrycie stref martwych TOFD, 
pozycjonowanie wskazań w kierunku osi y, możliwość określenia rodzaju niezgodności czy weryfikacja poprawności klasyfikacji wskazań TOFD (wewnętrzne, wychodzące na powierzchnię) w obszarach o niewystarczającej rozdzielczości przestrzennej (w pobliżu powierzchni skanowania). Z drugiej strony ograniczenia techniki PA są skutecznie uzupełniane poprzez TOFD. Ma to miejsce przy precyzyjnym wymiarowaniu głębokości i wysokości wskazań, wykrywaniu nieciągłości płaskich zorientowanych niekorzystnie (przyklejenia międzywarstwowe) czy wykrywaniu nieciągłości znacznie rozpraszających wiązkę ultradźwiękową (gniazda pęcherzy). Cechy te predestynują badania PA+TOFD do szerokiego zastosowania w kontroli jakości złączy spawanych, zwłaszcza tych o najwyższej odpowiedzialności. Jednakże, aby było to możliwe, niezbędny jest intensywny proces wdrażania ich do polskiego spawalnictwa, polegający na upowszechnianiu technik PA i TOFD w krajowym środowisku spawalniczym, a także kształceniu personelu badań nieniszczących w zakresie tych technik badawczych. Przy tak wysoce wyspecjalizowanych technikach badań zdecydowanie nie wystarcza tutaj wiedza i doświadczenie wyniesione z kursu konwencjonalnych badań ultradźwiękowych. Niezbędny jest specjalnie przeszkolony personel, zarówno w aspekcie wykonywania i oceny badań, jak i przygotowywania i walidowania procedur badawczych dla technik PA i TOFD. Działania te niewątpliwie podwyższą jakość i niezawodność wytwarzanych w kraju wyrobów spawanych, i tym samym, znacznie zwiększą atrakcyjność producentów stosujących te techniki badawcze jako narzędzie kontroli wytwarzanych złączy.

\section{Literatura}

[1] J.P. Charlesworth, J.A. Temple: Engineering Applications of Ultrasonic Time-of-Flight-Diffraction, Research Studies Press, Baldock, 2001.

[2] S. Mackiewicz, J. Kopiński: Doświadczenia z zastosowań ultradźwiękowej techniki TOFD, Materiały VII Seminarium „Nieniszczące Badania Materiałów", Zakopane 14-16 marca 2001

[3] R. Kaczmarek, K. Kaczmarek, J. Słania, R. Krawczyk: Wykonywanie badań ultradźwiękowych techniką TOFD w aspekcie wymagań norm przedmiotowych, Biuletyn Instytutu Spawalnictwa, nr 4, 2016.

[4] K. Kaczmarek, P. Irek, Ł. Rawicki, J. Słania: Wykrywanie niezgodności w złączach spawanych za pomocą techniki czasu przejścia wiązki dyfrakcyjnej (TOFD), Biuletyn Instytutu Spawalnictwa, nr 5, 2016.

[5] M. Śliwowski: Badanie obwodowych złączy spawanych gazociągów zmechanizowanym systemem ultradźwiękowym TOFD+PE. XXII Naukowo-Techniczna Krajowa Konferencja Spawalnicza, Międzyzdroje, 17-19.05.2016.
[6] S. Mackiewicz, M. Zgutka: Ultradźwiękowe badania złączy spawanych techniką Phased Array, XXI Seminarium Nieniszczące Badania Materiałów, Zakopane, 18-20 marca 2015.

[7] S. Mackiewicz: Badania złączy spawanych techniką phased array w świetle wymagań PN-EN ISO 13588, Przegląd Spawalnictwa, Vol. 87, nr 12, 2015.

[8] K. Kaczmarek, J. Słania: Wykrywanie niezgodności spawalniczych ultradźwiękową techniką TOFD, 45 Krajowa Konferencja Badań Nieniszczących, Kołobrzeg, 18-20 października 2016.

[9] R. Kaczmarek: Problematyka wskazań od geometrii w konwencjonalnych badaniach ultradźwiękowych oraz badaniach Phased Array, Biuletyn Instytutu Spawalnictwa, nr 2, 2017.

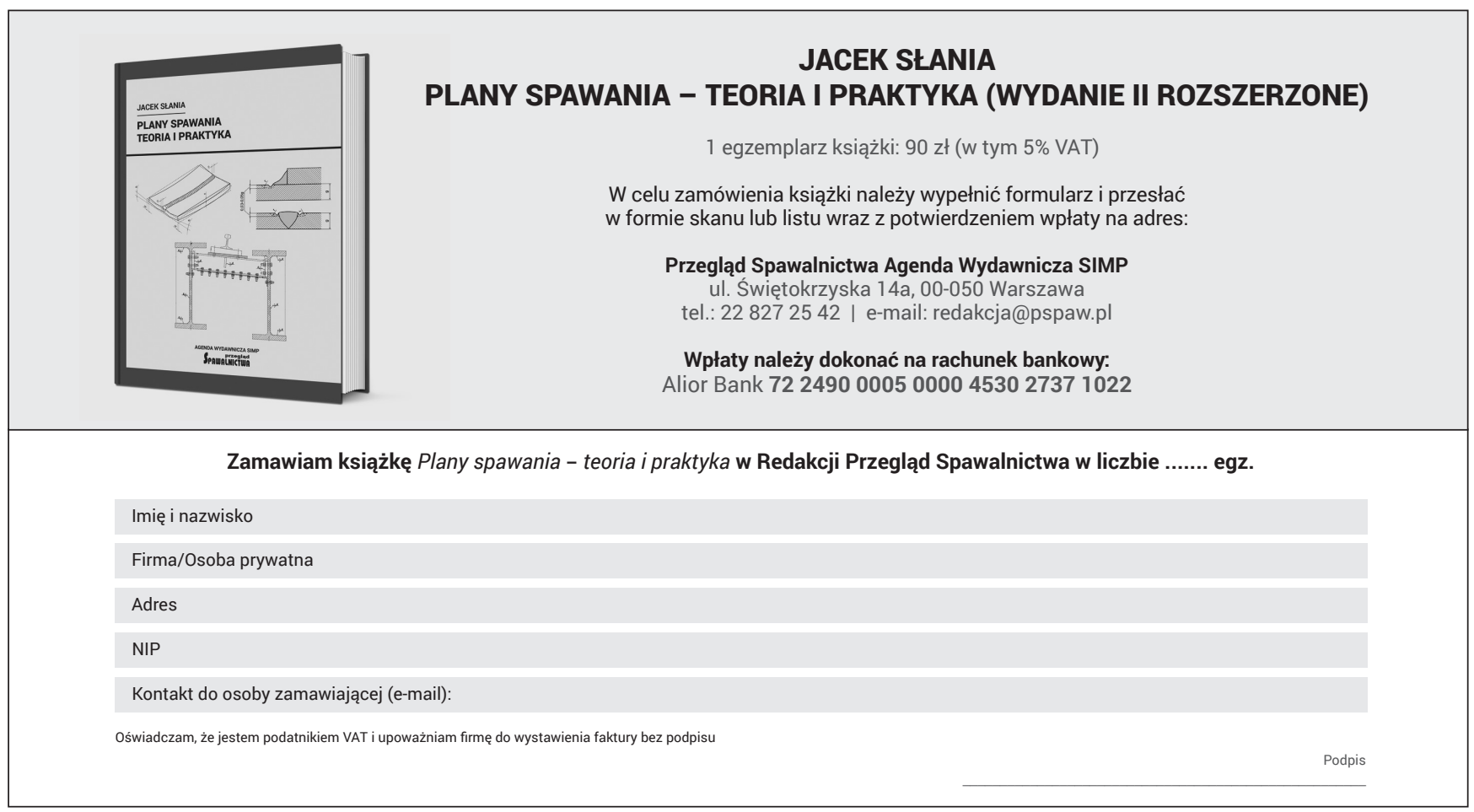

